ESTUDOS GERAIS

\title{
O DASP e a Administração Pública Federal
}

\author{
IsNARD Garcia DE Freitas
}

$\mathrm{O}$

DASP foi instituido num momento de transição da administração pública brasileira; em outras palavras, êle foi criado numa época em que a administração pública se tornava, dia a dia, mais complexa, tendo que enfrentar problemas novos da vida brasileira, tanto no campo econômico como no social. Os serviços públicos, consideràvelmente ampliados, exigiam quadros de pessoal mais especializado e mais bem adestrado. Os orçamentos públicos reclamavam o emprêgo de técnicas novas de previsão e programação, uma vez que deviam refletir programas de govêrno de muito maior alcance e diversificação. Lògicamente, a estruturação dos serviços da administração, os métodos de trabalho, os equipamentos materiais etc., todos êstes instrumentos deviam ser adaptados às responsabilidades de uma administração caminhando no ritmo de uma sociedade em desenvolvimento.

Não tenho dúvida em afirmar que a contribuição do DASP, nos 28 anos de sua existência, foi das mais positivas. Como órgão de cúpula da administração geral, colocado junto ao Presidente da República e no centro de um «sistema» de órgãos que se ramificam pelos diversos ministérios e outros grandes setores do serviço público, êle não só foi o pioneiro dos grandes movimentos visando melhor aparelhar a administração federal, no que toca ao elemento humano, ao elemento material, à organização e a métodos, como ainda contribuiu, de forma expressiva, para levar às próprias administrações estaduais e a muitas administrações locais uma assistência técnica das mais valiosas para a solução de problemas administrativos naquelas esferas. E ainda hoje é o Departamento o grande centro de estudo dos problemas administrativos, seja na fase de preparação de projetos a serem submetidos à aprovação do Congresso, seja na de regulamentação de normas legais, seja, ainda, no exame da imensa variedade de casos, individuais ou de grupos, surgidos na aplicação das leis e regulamentos. Um antigo dirigente do Departamento, dos mais ilustres, autor de interessante ensaio sôbre o DASP, publicado há alguns anos, intitulou-o «Uma 
Instituição a serviço do Brasil». Creio que o DASP continua a servir bem ao Brasil.

A supressão do DASP, pura e simples, seria absurda.

Estou certo, mesmo, que dela não se cogita, pois pronunciamento recente do $\mathrm{Exm}^{\circ} \mathrm{Sr}$. Presidente da República, na data em que o Departamento festejava o seu $28^{\circ}$ aniversário, mais uma vez deixou claro que o Govêrno sempre considerou o DASP um importante instrumento de administração. $\mathrm{Na}$ sua movimentada existência, o DASP foi alvo de certas investidas visando cortar algumas atribuições ou mesmo visando a sua extinção, mas tais investidas não chegaram a constituir perigo sério, porque o bom senso de muitos sempre se opôs ao açodamento ou leviandade de uns poucos. Não obstante, o DASP, como qualquer outra instituição, deve acompanhar a marcha do tempo. Assim, deve-se admitir, em principio, que o Departamento possa vir a sofrer algumas alteraçöes, a fim de melhor se apareihar para o atendimento das necessidades da administração. Não há fórmulas milagrosas em matéria de organização (e isto se aplica também ao DASP), cujo sucesso depende da excelência dos meios humanos e materiais postos a serviço da mesma. Assim, antes de tentarmos soluções novas, temos o dever de estudar em profundidade os sistemas ou fórmulas que já tenham uma tradição, uma experiência, para ajustá-los às necessidades.

O DASP deve ser o órgão central de pessoal da administração federal, não de caráter executivo em tudo que se refira às relações com o funcionalismo, mas um órgão de estudo, de consulta, de normalização, de contrôle superior. Os concursos para os cargos públicos, em que o Departamento adquiriu uma grande experiência assim como uma reputação de seriedade que constitui um dos seus mais valiosos títulos, são um outro exemplo de atividade legítima do Departamento, reconhecida pela opinião pública em geral. Os estudos relativos a estruturas e métodos de trabalho dos serviços da administração são adequados a um órgão do tipo do DASP, desde que aparelhado do elemento humano que tais tarefas, altamente técnicas, exigem. A elaboração orçamentária, campo no qual o Departamento adquiriu uma longa experiência e no qual ela ainda se faz valer, é atividade que se harmoniza com as demais citadas, dando ao Departamento um cunho de verdadeiro órgão central de administração geral, principal instrumento no qual se deve apoiar o Chefe do Executivo na sua missão de dirigente da administração. Esta última função exige um perfeito entrosamento com os órgãos de planejamento do govêrno, a fim de que o orçamento, na verdade, reflita um programa de govêrno.

Está na ordem do dia o projeto de Reforma Administrativa. Nesta, o DASP deve assumir posição do maior relêvo, pois a reforma da administração, como é entendida - isto é; ùm processo 
contínuo e não um esfôrço momentâneo destinado a imprimir uma feição definitiva à máquina administrativa - constitui, em última análise, o objetivo final do Departamento, definido na lei que o criou. Trata-se, é certo, de uma responsabilidade da maior importância, para a qual o DASP deverá ser reaparelhado. É sabido que muitos dos elementos com que o órgão poderia e deveria contar para o desempenho normal de suas atribuições estão fora dêle, prestando colaboração a outros setores do serviço público. Mas o DASP poderá renovar os seus quadros, criando novas oportunidades e oferecendo atrativos reais a elementos que todos os anos saem das nossas universidades e escolas de administração. UIma reformulação da politica do pessoal em bases novas seria para isso necessária. 